\title{
Nilai Ekonomi Sadranan Perspektif Masyarakat Bukan Pengguna Melestarikan Budaya Sadranan
}

\author{
Sri Walyoto \\ Fakultas Ekonomi dan Bisnis Islam IAIN Surakarta, Indonesia \\ *Email korenpondensi: sri.walyoto@iain-surakarta.ac.id
}

\begin{abstract}
The purpose of this study was to determine the value of the Cepogo sadranan cultural tradition from the perspective communities to form Non Use Value. Non Use Value is value a combination of opsyen values, existence, heritance that forms Passive value. The research was conducted on the community not users in Central Java. The Contingent Valuation Method (CVM) was used in this study. Multiple linear models are used to find out the variables studied are and explained by independent variables (distance, income, age). The results of the study of the independent variables significantly can explain the variables studied the willingness of the community not the user to pay (WTP) to preserve the cultural tradition of Cepogo sadranan. An organization that manages sadranan culture preservation funds is needed so that the understanding of future generations can still preserve the sadranan cultural tradition as a vehicle for unifying community friendship.
\end{abstract}

Keywords: Sadranan Culture Preservation, CVM, WTP

Saran sitasi: Walyoto, S. (2019). Nilai Ekonomi Sadranan Perspektif Masyarakat Bukan Pengguna Melestarikan Budaya Sadranan. Jurnal Ilmiah Ekonomi Islam, 5(03), 181-196. doi:http://dx.doi.org/10.29040/jiei.v5i3.676

DOI: http://dx.doi.org/10.29040/jiei.v5i3.676

\section{Pendahuluan}

Pelestarian budaya usaha melindungi, merawat, objek yang memiliki nilai untuk dilestarikan. Cara melestarikan dengan mempelajari, mengenal ikut mempraktekkan dalam kehidupannya. Ikut berpartisipasi pada kegiatan dalam rangka pelestarian budaya. Demikian juga yang dilakukan masyarakat Cepogo, Boyolali, Jawa Tengah Indonesia sebagai usaha melestarikan budaya sadranan. Budaya sadraran adalah upacara adat berdoa bersama mohon pada Alloh SWT agar arwah para leluhurnya diterima amal perbuatan dan diampuni dosanya.

Sadranan dilaksanakan pada bulan Ruwah (Sya'ban) menjelang Puasa (Ramadhan) setiap tahunnya. Penduduk desa secara bersama-sama datang kemakam dengan membawa aneka makanan untuk berdoa bersama-sama dan saling menukarkan perbekalan dengan handaitaulan. Setelah pulang dari doa bersama mereka saling berkunjung ketetangga maupun sanak famili. Mereka mempunyai kepercayaan semakin banyak tamunya maka rejekinya akan berlimpah. Maka budaya sadranan ini juga merupakan budaya kegotong-royongan, oleh karenanya perlu dilestarikan secara bersama pelaksanaannya sehingga budaya sadranan tetap ada.

Nilai ekonomi budaya perlu mendapatkan perhatian pemerintah dan masyarakat. Budaya merupakan identitas bangsa yang harus 
dihormati dan dijaga serta dilestarikan agar kebudayaan tidak punah dan menjadi warisan generasi akan datang. Budaya bangsa yang beranekaragam berpotensi menjadi keunggulan dan menjadi tantangan untuk mempertahankan budaya tersebut agar tidak menjadi milik bangsa lain. Kebudayaan dapat menjadi daya tarik wisatawan baik domestik maupun manca negara. Sebagaimana negara tetangga (Singapura, Malaysia, Thailand) pariwisata halal dapat menjadi sub sektor ekonomi serta menyumbang devisa sebagai bagian pendapatan negara.

Budaya dan halal dalam dunia Pariwisata dapat memainkan perannya dalam menyajikan keanekaragaman budaya yang kaya keunikan kenyamanan wisatawan muslim. Melalui promosi pembangunan pariwisata halal dapat dikenal. Persyaratan penting untuk memastikan pengembangan pariwisata halal adalah ketersediaan modal yang memadai untuk konservasi dan pemeliharaan. Karakteristik umum pengelolala pariwisata halal di negara berkembang disebabkan kurangnya pemahaman bahwa muslim luar daerah maupun negara lain mereka perlu keyakinan kehalal minuman makanan obyek.

Budaya lokal banyak yang luntur akibat kurangnya generasi penerus yang mewarisinya. Perlu menumbuhkan kesadaran secara sukarela karena pengaruh dari nilai sosio-kultural Jawa yang bersifat adikodrati. (Sardiman, 1992). Generasi penerus diperlukan untuk mewarisi kekuatan budaya lokal agar ada. Peran pemerintah dalam upaya pelestarian kebudayaan daerah adalah kebijakan-kebijakan yang mengarah pada upaya pelestarian budaya tersebut. Salah satu kebijakan pemerintah yang pantas didukung adalah penampilan budayabudaya daerah disetiap event-event nasional maupun lokal. Budaya yang ditampilkan itu adalah warisan generasi pendahulu.

Budaya dikembangkan untuk menangani tantangan hidup manusia yang semakin komplek. Budaya diperkenalkan pertama kali oleh seorang antropolog Edward Bernett Taylor sekitar tahun 1871. Beliau mendefinisikan budaya sebagai keseluruhan yang kompleks mencakup pengetahuan, kepercayaan, seni, moral, hukum, adat dan setiap kemampunan lain serta kebiasaan yang diperoleh manusia sebagai anggota masyarakat (Susanto et al. 2008). Pandangan dari ilmu sosologi, budaya lebih merupakan sikap dari anggota masyarakat dalam menghadapi fenomena yang berlaku disekitarnya.

Peranan budaya dalam pembangunan ekonomi bangsa dapat dilihat dari dua sisi. Pertama, sebagai instrumen untuk mempromosikan kemajuan ekonomi. Kedua, budaya merupakan ciri-ciri peradaban yang memberikan arti keberadaan masyarakat suatu negara. Budaya dan pembangunan ekonomi juga berdekatan dengan pembangunan insani. Pembangunan juga memerankan budaya sebagai sub set di satu sisi dan sebagai bagian dalam kelompok masyarakat tersebut.

Apabila konsep budaya dan pembangunan diperthitungkan secara bersama-sama keduanya merupakan bagian dari budaya masyarakat. Budaya seharusnya tidak diartikan secara sempit sebagai benda tetapi perlu lebih difahami sebagai tujuan atau hasil dari suatu proses yang berperingkat. Pandangan antropolog Marshal dan Sahlin hubungan budaya dan ekonomi sangat inklusif. Budaya sebagai penguat dapat ditafsirkan sebagai nilai dari kelompok dan pembangunan yang merupakan proses untuk memperbesar kesempatan manusia dalam memilih sumber alam yang terbatas.

Gotong royong merupakan budaya daerah di Indonesia merupakan ujud kebersamaan antar warganegara. Saling menolong atau saling memberi merupakan ujud dari budaya gotongroyong. Dalam suatu daerah upacara bersama-sama merupakan upaya melestarikan budaya gotongroyong. Sebagaimana sadranan yang dilakukan oleh penduduk di Kecamatan Cepogo Kabupaten Boyolali Jawa Tengah Indonesia. Tradisi budaya tersebut perlu pelestarian dan pemahaman yang benar mana yang menjadi wilayah budaya dan mana yang menjadi wilayah agama (Arivia, 2015). 
Throsby (1997) menyatakan pembangunan ekonomi bangsa dan budaya saling berhubungan. UNESCO melalui World Commission on Culture and Development (WCCD) telah menyatakan, bahwa pembangunan berkelanjutan suatu negara menempatkan budaya menjadi bagian yang penting. Kayam (1996) berpandangan bahwa budaya bukan suatu yang kongkrit dan memiliki batasan. Budaya dapat menjadi variabel yang dapat mempengaruhi perkembangan fenomena. Budaya juga merupakan suatu proses dialektik dinamik. Unsur-unsur yang terlibat dalam proses dialektik tersebut diantaranya adalah sistem ekonomi.

Budaya dalam ilmu ekonomi baik mikro maupun makro digunakan di berbagai bidang yang dipadukan dengan istilah lain. Seperti modal sosial (Soo-Hoon Lee et al. 2005), modal kepandaian (Caroll \& Tansey, 2000), serta modal budaya (Trosby 1999). Modal sosial dan modal kepandaian merujuk modal bukan fisik tidak nampak yang dimiliki oleh masyarakat. Selanjutnya modal budaya digunakan dalam menjelaskan sesuatu yang berbeda dengan arti yang berbeda pula. Dalam Teori Weber, modal budaya didefinisikan sebagai efisiensi dalam masyarakat.

Arti dan peranan budaya dalam ekonomi produksi telah banyak diketahui kepentingannya antara lain sebagai modal. Modal budaya dapat sebagai sumber alam yang dimiliki oleh sesuatu lembaga atau negara. Keberadaan sumber alam tersebut menentukan perkembangan, kemajuan lembaga atau negara tersebut. Seperti yang dinyatakan oleh Abeysekera (2007) modal kepandaian memiliki peran utama dalam perubahan ekonomi global akhir-akhir ini.

Modal dalam pendekatan ekonomi dapat dibedakan menjadi dua. Pertama, dapat berupa benda fisik yang nampak (tangible capital). Modal dalam bentuk benda fisik dapat berupa bentuk: bangunan, tempat, objek, karya seni, dan bentuk kekayaan alam. Kedua, modal dalam bentuk bukan fisik yang tidak nampak (intangible capital). Modal jenis kedua ini dapat berupa modal sosial (social capital), modal kepandaian (intelectual capital) berupa budaya, idea, keyakinan, nilai yang dianut bersama oleh kelompok masyarakat.

Modal budaya fisik maupun bukan fisik yang dimiliki oleh suatu negara, dapat diberlakukan sebagai dasar keunggulan bersaing yang dapat menghasilkan. Ia juga dapat sebagai sumber dana untuk daerah maupun negara dimana budaya tersebut berada. Kedua, jenis budaya tersebut jika mampu mengoptimalkan akan menghasilkan pendapatan yang tidak kecil. Kemampuan mengoptimalkan sumber alam yang dimiliki akan membentuk sebuah kompetensi inti untuk suatu negara atau bangsa.

Budaya dapat menjadikan keunggulan bangsa suatu negara. Black dan Porter (2000) mengutarakan bahwa keunggulan bersaing dapat diciptakan melalui melakukan suatu yang lebih baik dari apa yang dilakukan orang lain, melakukan suatu yang sukar dilakukan orang lain, melakukan suatu yang bernilai, melakukan suatu yang sukar digantikan dan melakukan sesuatu yang mengandung bayaran manfaat yang lebih tinggi. Budaya adalah salah satu jawaban itu semua. Karena budaya bukan semata-mata wujud sebagai benda fisik dan merupakan tujuan bertingkat dari proses dialektik maka budaya memberikan pengaruh unik yang berbeda dengan yang lain. Artinya bahwa karya budaya merupakan keunikan yang menjadi keunggulan negara dan bangsa.

Keunggulan kompetitif diciptakan melalui kelompok beberapa sumber yang unik. Sumber yang dimiliki oleh suatu negara sebagian merupakan sumber berwujud (tangibles asset) dan sebagian yang lain sumber tidak berwujud (intangible asset). Kedua jenis sumber tersebut merupakan sumber kompetensi inti. Nilai strategis dari sumber tersebut ditunjukkan oleh sumbangan yang dapat diberikan pada kemampuan pembangunan sebagai inti efisiensi dan keunggulan kompetitif negara. Seperti telah diuraikan budaya dapat memberikan sumbangan devisa bagi negara. Artinya budaya memiliki peranan sebagai sumber efisiensi inti dan selanjutnya menjadi sebuah keunggulan suatu negara. 
Kompetensi inti dapat dibangun dan diujudkan dengan dorongan sumber alam yang dimiliki. Pembangunan kompetensi inti yang mempunyai daya tahan dapat dilakukan dengan dua cara. Pertama, pemberian kriteria yang khusus dari sumber dan berupaya menjadi kompetensi inti. Kedua, Analisis Rantai Nilai (value chain). Analisis ini digunakan untuk memilih ciptaan kompetensi inti yang harus dipelihara, ditingkatkan dan diujudkan. Selanjutnya, jika budaya dijadikan sebagai salah satu modal bangsa, maka perlu dipelihara, dikembangan atau dikemas agar menjadi lebih bernilai.

Sumber alam utama sebagaimana dikemukakan Hit et al. (2001) mempunyai nilai (valuable). Keberadaannya terbatas bersifat langka tidak mudah ditiru serta unik. Sumber yang tidak berwujud, seperti budaya, daya kreativitas dan keahlian yang dimiliki sumber insani lebih bersifat unik dibanding dengan sumber berwujud. Budaya yang unik tidak dapat digantikan dan ini menjadi ciri-ciri yang dimiliki oleh budaya bangsa tertentu. Sebagai contoh, budaya suku Dayak, budaya suku Toraja, budaya suku Asmat yang tidak dapat dicipta oleh bangsa lain.

Suatu bangsa perlu memikirkan dan berusaha agar budaya mampu memberikan dukungan sehingga tercapai pembangunan ekonomi yang berkelanjutan. Bangsa dan negara yang mampu membangun ekonomi secara berterusan serta dapat menciptakan keunggulan kompetitif. Pembangunan berwawaskan budaya dapat mengurus sumber, berkemampuan dan efisiensi secara signifikan termasuk di dalamnya adalah modal budaya.

Berbagai keunikan budaya dan alam merupakan anugerah Tuhan. Keunikan tersebut menjadikan daya tarik dan ia berbeda. Keunikan inilah sepatasnya ideal menjadi modal dasar, khususnya modal budaya. Suatu negara misal seperti Singapura yang tidak mempunyai berbagai kekayaan alam seperti Indonesia, tetapi mampu menciptakan keunikan yang menjadi daya tarik. Berbagai acara, pameran, atau hanya pertemuan telah banyak dilakukan oleh pebisnis internasional. Demikian juga China daratan yang mempunyai pariwisata tradisional dan Hongkong sebagai tujuan pariwisata moderen.

Pemerataan kepentingan generasi berdasarkan pada keadilan distribusi kemakmuran, kegunaan (utility) atau distribusi sumber antar generasi. Prinsip dasar pemerataan kepentingan generasi dapat difahami dalam konteks wawasan generasi demi generasi. Jika berdasarkan pada konsep budaya, bahwa budaya bukan merupakan produk akhir tetapi merupakan hasil dialektika suatu masyarakat. Hasil dialektika tersebut akan memunculkan inovasi dan pembaharuan sehingga akan mewarnai budaya yang sudah ada atau dapat memperkaya.

Proses memperkaya dan mewarnai budaya yang ada dilakukan oleh masyarakat dalam peradaban maupun konteks tertentu. Ia akan terus berlangsung dari generasi ke generasi. Pada akhirnya akan menjadi suatu modal sendiri yang bernilai tinggi bagi suatu generasi. Budaya yang lebih kaya akan menjadi modal sendiri dari generasi ke generasi seterusnya. Budaya hasil ciptaan generasi akan menjadi daya tarik tersendiri yang mampu menopang ekonomi bangsa. Oleh karena itu perlu pembangunan berkelanjutan untuk melestarikan budaya.

Pembangunan berkelanjutan (sustainability development) adalah sebuah konsep pembangunan yang telah di kenal mulai tahun 1970-an. Konsep tersebut menekankan bahwa pembangunan suatu bangsa perlu mempertimbangkan atau berfikir generasi yang akan datang. Pembangunan berkelanjutan meliputi beberapa lingkup diantaranya pembangunan ekonomi dan pembangunan budaya dan sosial. Dimana peningkatan kesejahteraan generasi sekarang juga tidak menghilangkan kesempatan generasi akan datang untuk menikmatinya.

Konsep pembangunan berkelanjutan mempunyai arti bahwa pembangunan tidak hanya dimaknai sebagai pembangunan ekonomi, namun juga sebagai alat untuk mencapai kepuasan intelektual, emosional, moral, dan 
spiritual. Dalam pandangan ini, berbagai budaya merupakan salah satu dasar yang menjadi sebahagian dari lingkup dasar pembangunan yang berkelanjutan dan terorganisir. organisasi untuk memahami dirinya sendiri dan dapat membangun lingkungan organisasi yang efektif (Debby, 2015).

Budaya dan aneka ragam budaya menjadi salah satu pendukung pembangunan sosial, ekonomi dan lingkungan selain kekayaan alam yang bersifat fisik. Maka penempatan budaya sebagai modal pembangunan menjadi suatu yang penting. Bangsa dan negara yang memiliki modal tersebut idealnya menjadi negara yang mempunyai efisiensi dan keunggulan bersaing bagi pembangunan ekonomi (Landiyanto dan Wardaya 2009).

Agenda 21 dalam Bab 26 terdapat dukumen penting pengakuan dunia kepada masyarakat adat sebagai bagian dari pembangunan berkelanjutan. Sebagai negara yang mendukung dan menandatangani Deklarasi Lingkungan Hidup Internasional, dalam melaksanakan pembangunan ekonomi harus sesuai dengan aspirasi bangsa. Ini termasuk aspirasi masyarakat adat yang juga merupakan bagian dari bangsa tersebut. Mereka hidup, memiliki pengetahuan dalam pengobatan, pertanian, pemeliharaan daerah aliran sungai (DAS), pemanenan sumber alam secara berkelanjutan adalah asset dalam perencanaan pembangunan berkelanjutan (Ravi Goval 2005). Asset tersebut menjadi bagian keaneka ragaman budaya dunia.

World Wide Fund for Nature (WWF) 2000 meneliti tentang keanekaragaman hayati daerah, dan masyarakat adat tradisional di dunia serta pemeliharaan, telah mendukumentasikan kehancuran bahasa yang diucapkan oleh masyarakat adat diseluruh dunia. Kegagalan untuk mendukumentasikan pengetahuan masyarakat adat telah menyebabkan kehancuran bahasa secara signifiken, yang menyebabkan kehilangan pengetahuan lingkungan dari budaya tradisional. Seperti yang disebutkan oleh (Hood Salleh et al. 2004).
Menurut Daniella Tibury seperti dikutip dalam Daniel Gil-Perez et al. (2003) lingkungan dan masalah pembangunan tidak semata-mata disebabkan oleh faktor fisik dan biologi. Pemahaman dari bagian-bagian tersebut dimainkan oleh elemen estetika, sosial, ekonomi, politik, sejarah dan budaya. Dalam kontemporer internasional mendukumentasikan adat pengetahuan tentang lingkungan akan mengakibatkan pengetahuan lebih lanjut tentang perspektif budaya dan sejarah. Ravi (2005) memberikan komentar bahwa begitu banyak kekayaan peradaban yang dibangun selama bertahun - tahun telah hilang karena modernisasi.

Berkembangnya semangat manusia begitu nyata dan indah, dan itu sangat menyedihkan bahwa banyak dari kecerdikan dan budaya manusia telah hilang. Perkembangan teknologi komunikasi dan globalisasi ekonomi pada dasarnya membawa konsekuensi terhadap nilai dan gaya hidup suatu masyarakat (Agus Maladi Irianto, 2017). Orang Indian Maya di Amerika Tengah yang ada pada tahun 2000 SM adalah petani sukses yang telah membangun beratusratus kota-kota besar dari batu, masing-masing dengan watak sendiri dan gaya artistik. Maka keharmonisan pembangunan dan budaya masyarakat adat perlu dijaga pemerintah setiap negara agar peradaban budaya adat yang bernilai tinggi tidak hilang karena pembangunan.

Whitmore 1991, dalam penelitiannya sejarah mengenai Suku Anak Dalam di Bukit Duabelas nenek moyangnya adalah suku Kubu, yang termasuk bangsa nomad, penghuni hutan tropis, semenjak peradaban dahulu kala. Sedang Weintre 2003, menyatakan nenek moyang Suku Anak Dalam adalah sisa perjurit Kerajaan Sriwijaya yang pada tahun 1025 kalah perang. Irma 2010, berpendapat nenek moyang Suku Anak Dalam adalah perantau dari Pagar Ruyung yang kawin dengan putri Kelumpang selanjutnya anak keturunanya adalah Suku Anak Dalam. Walyoto (2011) berpendapat budaya Suku Anak Dalam keharmosisannya dengan alam dan lingkungan perlu di konservasi agar lestari. 
Nilai ekonomi budaya perspektif masyarakat bukan pengguna dapat diestimasi dari kesanggupan menerima atau mempertahankan. Oleh karena budaya merupakan benda tidak berujud, maka bisa terjadi kegagalan pasar dalam mengestimasi nilai ekonominya, dan dapat diukur menggunakan pendekatan harga bayangan. Kesediaan masyarakat sanggup menerima atau mempertehankan budaya tersebut tetap ada dapat didekati dengan kesediaan WTP/WTA.

Kesediaan membayar (WTP) dan kesediaan menerima (WTA) dalam Contingen Valuation Method (CVM) dapat diperoleh langsung dari individu. Metode penilaian ini berdasarkan pilihan yang dinyatakan dan menggunakan metode kurve permintaan kompensasi (Hicksian) dimana analisis untuk memperoleh nilai kesejahteraan dalam bentuk surplus kompensasi atau surplus setara.

Jika mendasarkan pada bias strategi responden tidak memberikan nilai WTP atau WTA. Keadaan tersebut mungkin terjadi jika ia beranggapan asumsi tersebut tidak benar-benar terjadi atau sebaliknya. Langkah untuk mengurangi bias, Mitchell dan Carson memberikan pemecahan dengan memisahkan WTP kesanggupan dengan harga rata-rata dan merahasiakan WTP yang diberikan kepada orang lain (Hanley \& Spash 1993).

Penelitian ekonomi kesejahteraan biasanya fokus untuk memaksimumkan kesejahteraaan sosial. Pengukuran perubahan kesejahteraan individu melaluli pengukuran utilitas secara tidak langsung. Apa yang dianggarkan adalah WTP individu yang diungkapkan dalam nilai uang untuk menggambarkan fungsi utilitas individu tersebut. Hicks memperkenalkan ukuran surplus setara dan kompensasi, ukuran ini membentuk dasar CVM untuk barang non pasar dengan penggunaan analisis CBA (Jacobs 1997).

Contingen Valuation Method (CVM) adalah metode penilaian yang terkenal karena penggunaannya yang lebih luas. Sifat yang subyektif menyebabkan lebih dikenal sebagai metode penilaian validitasnya banyak menimbulkan kontroversi. Atas alasan yang sama satu daftar yang perlu diperhatikan sebagai pedoman untuk menghasilkan penelitian $\mathrm{CV}$ yang dapat dipergunakan.

Metode CVM pertamakali diperkenalkan oleh Davis selanjunya digunakan para ahli ekonomi. Ia diaplikasikan dalam penelitian teroritik dan empirik tahun 1970an dan 1989an terutama di AS. Sampai sekarang dalam penelitian penggunaannya terus dilakukan untuk penilaian sumber lingkungan dan budaya.

Penelitian-penelitian budaya yang telah menggunakan CVM diantaranya, Takaaki Kato menggunakan CVM dengan kusioner terbuba dengan format pembayaran sekali dalam satu tahun dan setiap bulan untuk melestarikan kampung nelayan di Maguro Jepang. Kusuma Indah menggunakan CVM untuk valuasi ekonomi nilai budaya suku Dayak Benuaq di Kalimantan Indonesia perannya dalam pemanfatan sumber hutan. Throsby menyatakan bahwa CVM sekarang telah digunakan sebagai alat ukur permintaan barang non pasar (barang budaya).

Untuk menentukan keberhasilan penelitian diperlukan penilaian penelitian CVM. Persoalan yang mungkin muncul yaitu kemungkinan terjadinya protes dari responden yang tinggi. Pemahaman terhadap hipotetik pasar yang rancang tergantung dari kemampuan pasar tersebut untuk memberikan pengetahuan responden terhadap pasar tersebut.

Pasar modal syariah merupakan salah satu alternatif investasi dengan saham syariah sebagai instrumen investasi yang menyatakan bukti penyertaan kepemilikan dalam perusahaanperusahaan yang berbasis syariah. Tandelilin (2011) mengemukakan investasi bisa didefinisikan sebagai komitmen sejumlah uang atau sumber daya lainnya yang dilakukan saat ini (present time) dengan harapan memperoleh manfaat (benefit) dikemudian hari (in future).

\section{Metode Penelitian}

Penelitan ini menggunakan CVM untuk mengestimasi nilai budaya sadranan masyarakat Cepogo perspektif masyarakat bukan pengguna. 
Data diperoleh secara langsung menggunakan kusioner. Penyusunan kuesioner merupakan elemen utama dalam menentukan kualitas data dan hasil penelitian. Pertanyaan dalam daftar yang ada disusun berdasarkan jenis informasi yang diharapkan. Populasi penelitian ini adalah masyarakat Jawa Tengah Indonesia yang tidak tau dan tidak ingin tau tetang budaya sadranan. Penetuan sampel berdasarkan pertimbangan mereka yang sudah dewasa berusia 17 tahun keatas yang diambil secara acak.

Penelitan ini memilih keluarga sebagai responden yang terdiri dari kepala keluarga tanpa membedakan jenis kelamin. Alasan pemilihan kepala keluarga didasarkan pada sumbangan utama dalam pendapatan dan pengambilan keputusan dalam keluarga, kepala keluarga juga memiliki informasi sesuai penelitian yang dilakukan. Sekiranya kepala keluarga tidak dapat diwawancarari, anggota keluarga lain yang telah berusia 17 tahun atau lebih dipilih sebagai responden.

Metode kontingen menggunakan asumsi responden bersedia menukarkan kepentingan barang bukan pasar dengan unit keuwangan. Ia memerlukan informasi pasar dan pilihan yang diceritakan kepada mereka. Pasar lingkungan dan budaya perlu diceritakan dengan hati-hati supaya penukaran dapat memuaskan. Penukaran perlu diceritakan perubahan yang terjadi sehingga responden memahami sepenuhnya, dan berupaya mengetahui tanpa dipaksakan. Berhubungan dengan pasar yang digunakan dalam kuesioner memuat tiga unsur berikut; keterangan perubahan lingkungan dan budaya, keterangan metode pembayaran dan sikap responden terhadap pelestarian budaya sadranan.

Unsur penting kuesioner telah didiskusikan dalam fukus grup. Panel setuju dengan metode pembayaran pelestarian budaya sadranan dan dikelola dengan sistem, serta sepakat dengan organisasi atau lembaga yang mengelola agar program berhasil sesuai tujuan. Penelitian ini melibatkan proses estimasi barang lingkungan dan budaya serta nilai maksimal barang pasar tersebut. Teknik yang digunakan untuk bertanya dan mencatat kesediaan seseorang membayar secara terbuka untuk barang lingkungan dan budaya. Teknik ini disebut format pertanyaan terbuka, responden diminta menyatakan kesanggupan membayar maksimum dan mereka dibantu dengan diberikan penerangan mengenai pasar yang diasumsikan dan metode pembayaran tidak ditentukan.

Penelitian ini melakukan uji coba untuk mendapatkan tanggapan dari responden atas pemahaman dan kesesuaian pertanyaan terhadap pernyataan pasar yang diasumsikan dalam kuesioner dan waktu untuk menjawab pertanyaan. Uji coba dengan melibatkan 60 responden. Kuesioner menggunakan format Pertanyaan Terbuka. Pasar yang diketengahkan untuk memperoleh tanggapan dari responden sanggup membayar. Responden dapat menerima dan memahami pasar yang diasumsikan.

Penelitian CV ini mempergunakan pasar kepunahan budaya sadranan. Untuk menjaga agar kepunahan tidak terjadi perlu adanya pemahaman dalam regenerasi, untuk keperluan tersebut perlu dana untuk melestarikan. Responden diingatkan tentang budaya sadranan. Responden juga diingatkan masyarakat Cepogo yang sudah mentradisi melaksanakan sadranan. Pasar yang diilustrasikan dalam penelitian ini sebagai berikut: "untuk mempertahankan budaya sadranan, perlu dana untuk memberikan pemaknaan ativitas sadranan antara agama dan budaya. Uji coba kusioner untuk mengetahui reaksi dan tanggapan responden atas pemahaman dan kesesuaian persoalan terhadap pertanyaan pasar yang digunakan sebagai ilustrasi serta waktu untuk menjawab juga telah dilakukan sebelum penelitian benar-benar dilakukan.

Penelitian juga melakukan uji sensitivitas berdasar masyarakat yang meninggalkan budaya sadranan. Berkurang sebesar $10 \%$ banyaknya masyarakat yang tidak melaksanakan budaya sadranan. Berkurang sebesar 50\% banyaknya masyarakat yang tidak melaksanakan budaya sadranan. Berdasarkan syarat NOAA untuk memperoleh hasil penelitian CVM yang realible WTP untuk skop berkurang yang besar (50\%) 
harus lebih besar dibading dengan WTP untuk skop berkurang kecil (10\%). Penelitian ini telah dirancang seperti ini untuk mengetahui apakah WTP yang diperoleh berdasar jumlah secara spesifik berdasar unsur yang tidak melaksanakan budaya sadranan dijadikan dasar uji sensitivitas.

Budaya sadranan yang dinilai dengan CV berkaitan dengan lingkungan. Keterkaitan tersebut diantaranya budaya sadranan sebagai ujud kegotongroyongan sebagai manisfestasi kekompakan diantara warga masyarakat. Mereka akan mengelami penurunan kesejaheraannya jika tidak melaksanakan budaya sadranan. Agar kesejahteraan tidak turun mereka perlu melaksanakan budaya sadranan. Agar tidak terjadi berkurangnya masyarakat yang melaksankan budaya sadranan dan tidak terjadi pemahaman yang keliru antara buadya dan agama tentang sadranan maka adanya sosialisai.

Untuk kegiatan sosialisai perlu dana. Kesediaan masyarakat bukan pengguna bersedian mgengumpulkan dana untuk kegitan sosialisasi dalam penelitan adalah nilai $\mathrm{WTP}^{\mathrm{ES}}$ per responden untuk mempertahankan keberlanjutan budaya sadranan. Kurve berikut dapat menggambarkan masyarakat bukan pengguna agar budaya sadranan Cepogo tidak punah atau berkurang. Untuk mendapatkan nilai bukan pengguna agar terhindar kepunahan budaya sadranan (diwakili oleh pendapatan atau rata-rata dana yang sedia masyarakat bukan penguna bayar).

Kurve dibawah menggunakan analisis pilihan pengguna, rumah tangga dimisalkan berada di titik A pada kepuasan mula-mula $\mathrm{U}_{0}$. Pudarnya budaya sadranan akibat berkurangnya masyarakat yang melaksanakan sadranan digambarkan bergesernya titik A ke B pada kurve kepuasan $\mathrm{U}_{1}$. Kepudaran budaya sadranan $\left(\mathrm{q}_{1}\right)$ diandaikan tidak terjadi dengan catatan masyarakat perlu melakukan sadranan bersama. Agar dalam melaksakan budaya sadranan mereka sadar dan faham dapat memisahkan pengertian buday dan agama dengan baik diperlukan adanya kegitan sosialisasi. Kegitan sosialisasi tersebut diperlukan sejumlah dana untuk pekasanaannya. Dana yang terkumpul dari masyrakat bukan pengguna sebagai dana sosialisasi atau $\mathrm{WTP}_{\mathrm{ES}}$ digambarkan titik (D). Sehingga budaya sadranan tidak punah.

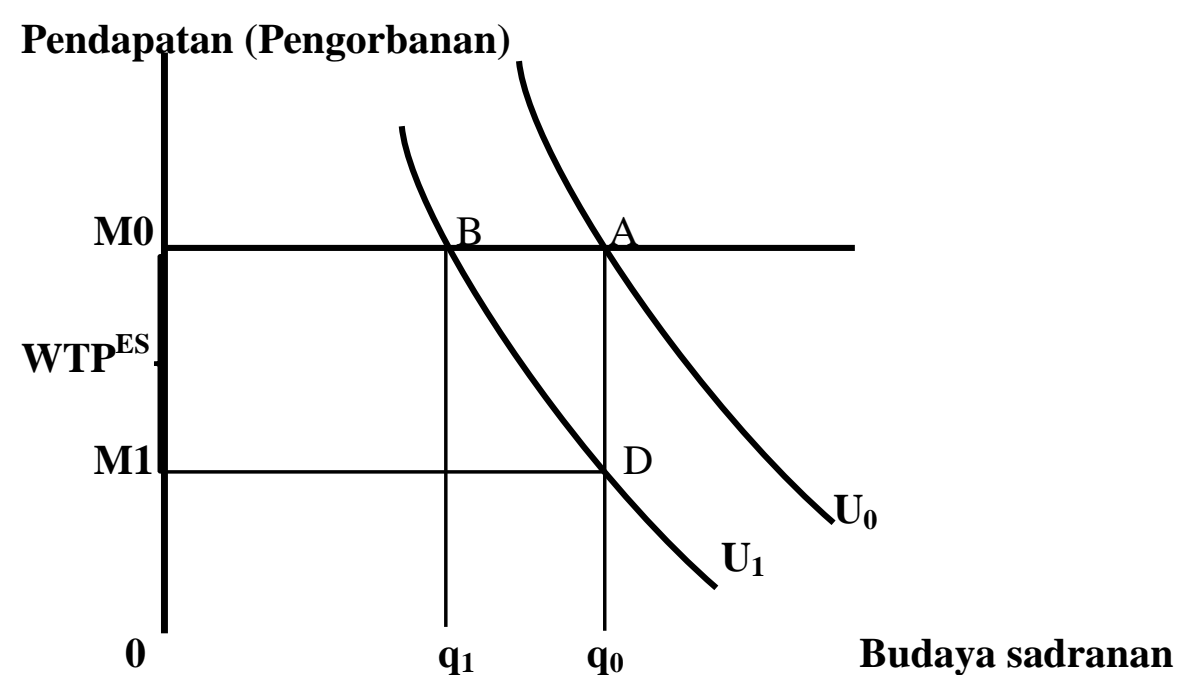

Untuk mengetahui faktor-faktor yang $U=$ usia (tahun)

menjadikan responden bersedia melestarikan budaya sadranan diduga dengan model regresi linear seperti model berikut:

$\mathbf{W T P}=\alpha+\mathbf{b}_{1} \mathrm{Dm}+\mathbf{b}_{2} \mathbf{P d t}+\mathbf{b}_{3} \mathrm{U}+\boldsymbol{\varepsilon}$

$\mathrm{Dm}=$ domisili responden/jarak $(\mathrm{km})$

$\mathrm{Pdt}=\operatorname{pendapatan}(\mathrm{Rp})$

$\varepsilon \quad=$ eror

Domisili responden terhadap budaya sadranan dalam model ini diharapkan berhubungan negatif dengan pelestarian budaya sadranan Cepogo agar tidak punah. Umur responden dijangka berhubungan positif dengan 
pelestarian budaya sadranan Cepogo. Pendapatan responden dijangka berhubungan positif dengan pelestarian budaya sadranan Cepogo.

Uji untuk mengetahui sensitivitas responden dalam memberikan WTP pelestarian tradisi dudaya sadranan Cepogo juga dilakukan pada penelitian ini. Dalam mendapatkan nilai WTP pelaksanaan sadranan Cepogo dengan $\mathrm{CV}$ format terbuka. Penelitian ini dilakukan dengan sampel dengan jumlah 400 responden. Untuk dapat mempercayai atau meyakinkan apakah parameter sampel dapat dipergunakan untuk menduga parameter populasi penelitian ini dilakukan dengan uji t.

\section{Hasil dan Pembahasan}

Generasi kini perlu mendapatkan pemahaman budaya tradisional yang dilakukan oleh genersi pendahulunya yaitu sadranan Cepogo. Pemahaman ini perlu adanya sosialisai agar tidak terjadi penafsiran yang keliru dan tradisi budaya sadranan antara budaya dan agama dan budaya tersebut tetap lestari. Tidak adanya upaya pemahaman dapat berpengaruh hilangnya nilai budaya yang dilakukan oleh generasi pendahulunya. Nilai budaya sadranan Cepogo persepsi masyarakat bukan pengguna membentuk nilai penggunaan pasif. Nilai penggunaan pasif (nilai opsyen, nilai kewujudan, nilai warisan). Komponen nilai bukan penggunaan ini juga dimiliki oleh masyrakat bukan pengguna.

Penelitian ini menggabungkan nilai opsyen, nilai kewujudan, nilai warisan, dalam komponen nilai pasif/nilai bukan gunaan (NBG) karena adanya kesulitan memisahkan setiap komponennya antara satu dengan yang lain. Populasi masyarakat bukan pengguna dalam penelitian CV lebih komplek. Populasi masyarakat bukan pengguna penelitian ini adalah penduduk Jawa Tengah yang belum tau dan tidak akan mencari tahu budaya sadranan Cepogo. Walaupun mereka tidak pernah melaksanakan tradisi budaya tersebut atau mendapat manfaat dari sumber lingkungan yang diteliti dimungkinkan ada pengaruh negatif atas kemerosotan perubahan tradisi budaya tersebut. Estimasi nilai budaya sadranan di Cepogo nilai bukan gunaan (NBG) di estimasi dengan CVM.

Uji skope untuk mengetahui penelitian dengan model CVM telah dilakukan sebelum data-data responden dikumpulkan. Rata-rata WTP penurunan masyarakat melaksanakan tradisi budaya sadranan Cepogo sebesar 50\% lebih besar dari rata-rata WTP masyarakat yang melakukan sadranan Cepogo berkurang $10 \%$. Pasaran yang dibangun "Tradisi budaya sadranan merupakan ujud kegotong royongan yang perlu dilestarikan dan menjadi keunikan masyarakat".Untuk melestarikan tradisi budaya tersebut diperlukan pendanaan guna sosialisai pemahaman generasi sekarang. Sosialisasi pemahaman tersebut memerlukan waktu. Andaian jangka waktu yang diperlukan selama 12 tahun semasa generasi tersebut masih berada pada tingkat pendidikan dasar sampai dengan pendidikan menengah atas.

Selanjutnya populasi penelitian di Jawa Tengah berdasar analis jarak mereka yang bertempat tinggal jarak diatas $100 \mathrm{~km}$ adalh termasuk Non Penggguna. Surakarta dan Brebes mewakili daerah non penggguna dengan responden masing 200. Responden ditanya cara melestarikan, mereka akan meberikan donasi sekali saja atau setiap tahun selama 12 tahun. Data yang diperoleh dari penelitian di tabulasikan sebagai berikut:

\subsection{Pendidikan Responden}

Pedidikan responden $4 \%$ responden tidak berpendidikan $29,2 \%$ renponden berpendidikan sekolah dasar, 33\% responden berpendidikan sekolah menengah pertama (SLTP), 30,3\% responden berpendidikan sekolah menengah atas (SLTA), dan 3,5\% renponden berpendidikan perguruan tingggi seperti tampak pada tabel berikut. 
Tabel. Pendidikan Responden

\begin{tabular}{|l|c|c|}
\hline $\begin{array}{c}\text { Tingkat } \\
\text { Pendidikan }\end{array}$ & Kuantitas & $\begin{array}{c}\text { Prosen } \\
(\boldsymbol{\%})\end{array}$ \\
\hline Tidak skolah & 16 & 4 \\
SD & 117 & 29,2 \\
SLTP & 132 & 33 \\
SLTA & 121 & 30,3 \\
Perguruan Tinggi & 14 & 3,5 \\
\hline \multicolumn{1}{|c|}{ Jumlah } & $\mathbf{4 0 0}$ & $\mathbf{1 0 0}$ \\
\hline
\end{tabular}

\subsection{Pekerjaan Responden}

Pekerjaan responden terbanyak adal pedagang dan petani sebanyak 37,8\%, dikuti oleh pegai negeri (PNS) sebanyak 30,5\%, swasta sebanyak $27,8 \%$ dan pelajar $4 \%$ seperti tampak pada tabel berikut:

Tabel Pekerjaan Responden

\begin{tabular}{||l|c|c|}
\hline \multicolumn{1}{|c|}{ Responden } & Kuantitas & $\begin{array}{c}\text { Prosen } \\
(\boldsymbol{\%})\end{array}$ \\
\hline Pegawai Negeri (PNS) & 122 & 30,5 \\
Swasta & 111 & 27,8 \\
Pedagang dan petani & 151 & 37,8 \\
Pelajar & 16 & 4 \\
\hline \multicolumn{1}{|c|}{ Jumlah } & $\mathbf{4 0 0}$ & $\mathbf{1 0 0}$ \\
\hline
\end{tabular}

\subsection{Usia Responden}

Usia responden kurang dari 21 tahun 2\%, sebanyak $18,5 \%$ berusia antara 21-34 tahun, sebanyak $61,2 \%$ berusia antara 35-48 tahun dan sebanyak $18,3 \%$ berusia lebih dari 48 tahun seperti tampak pada tabel berikut. Rata-rata usia responden 42 tahun.

\section{Usia Responden}

\begin{tabular}{|l|c|c|}
\hline \multicolumn{1}{|c|}{ Usia Responden } & Kuantita & $\begin{array}{c}\text { Prosen } \\
(\%)\end{array}$ \\
\hline Kurang dari 21 tahun & 8 & $2 \%$ \\
21 -34 tahun & 74 & 18,5 \\
35 - 48 tahun & 245 & 61,2 \\
Diatas 48 tahun & 73 & 18,3 \\
\hline \multicolumn{1}{|c|}{ Jumlah } & $\mathbf{4 0 0}$ & $\mathbf{1 0 0}$ \\
\hline
\end{tabular}

\subsection{Pendapatan Responden}

Pendapatan responden kurang dari 2 juta sebanyak $8 \%$, antara $>2$ juta sampai dengan 5 juta sebanyak $17,75 \%$, antara $>5-10$ juta sebanyak 52,5\% dan diatas 10 juta sebanyak $21,75 \%$ dengan rata-rata pendapatan 7,5 juta seperti tampak pada tabel berikut.

Pendapatan Responden

\begin{tabular}{|l|l|l|}
\hline $\begin{array}{c}\text { Pendapatan } \\
\text { Responden }\end{array}$ & Kuantitas & Prosen (\%) \\
\hline Kurang dari 2 juta & 32 & $8 \%$ \\
Antara $>2-5$ juta & 71 & $17,75 \%$ \\
Antara $>5-10$ juta & 210 & $52,5 \%$ \\
Lebih dari 10 juta & 87 & $21,75 \%$ \\
\hline Jumlah & 400 & 100 \\
\hline
\end{tabular}

\subsection{Domosili/jarak responden ke/dari Cepogo}

Domisili/jarak responden ke/dari Cepogo nampak seperti pada tabel berikut, dimana yang berdomisli/jarak antara $<100-150 \mathrm{~km}$ sebanyak $(4,25 \%)$ dan yang berdomisili antara $>150-200$ $\mathrm{km}$ sebanyak $42,5 \%$, berdomisili antara $>200$ $250 \mathrm{~km}$ sebanyak $20 \%$ dan domisili diatas 250 $\mathrm{km} \mathrm{km}$ sebanyak $33,25 \%$ dengan rata-rata domisili sejauh $275 \mathrm{~km}$.

\section{Domisili Respenden}

\begin{tabular}{|l|c|c|}
\hline Domisili Responden & Kuantitas & $\begin{array}{c}\text { Prosen } \\
(\mathbf{\%})\end{array}$ \\
\hline Domisili < $100-150 \mathrm{~km}$ & 17 & $4,25 \%$ \\
Domisili $>150-200 \mathrm{~km}$ & 170 & $42,5 \%$ \\
Domisili $>200-250 \mathrm{~km}$ & 133 & $32,25 \%$ \\
Domisili < 250 km & 80 & $20 \%$ \\
\hline \multicolumn{1}{|c|}{ Jumlah } & $\mathbf{4 0 0}$ & $\mathbf{1 0 0}$ \\
\hline
\end{tabular}

\subsection{Kesediaan responden WTP untuk} melestarikan tradisi budaya sadranan Cepogo

Kesediaan respoden melestarikan tradisi budaya sadranan Cepogo ada 2 (dua) bentuk yaitu dengan 1(satu) kali bayar selama hidup dan setahun sekali selama 12 tahun selama generasi masih berada pada pendidikan dasar sampai sekolah menengah atas. Sebanyak 48,5\% membanyar setiap tahun selama 12 tahun dan sebanyak 47,25 membayar sekali selama hidup. Model pembayaran sekali selama hidup dan setahun sekali selama 12 tahun seperti berikut:

Model pembayar setiap tahun selama 12 tahun, responden sebanyak 194 bersedia 
Jurnal Ilmiah Ekonomi Islam, 5(03), 2019, 191

membayar: 5 ribu rupiah sebanyak 17,5\%, 10 ribu rupiah sebanyak $13 \%, 12,5$ ribu rupiah sebanyak 5\%, 15 ribu rupiah sebanyak 5\%, 20 ribu rupiah sebanyak 5,75\%, 25 ribu sebanyak $1,25 \%$, dan 30 ribu lebih atau sebanyak $1 \%$.

Responden yang bersedia membanyar sekali selama hidup sebanyak 189 atau 47,25 adalah, sebanyak 50-100 ribu rupiah sebanyak $26,75 \%$, antara 101-200 ribu rupiah sebanyak 14,5\%, antara 201-300 ribu rupiah sebanyak 5,5\%, lebih dari 300 ribu rupiah sebanyak $0,5 \%$ seperti tabel berikut:

WTP 1 Tahun Sekali Selama 12 Tahun Membayar 1 Tahun sekali Selama 12 Tahun

\begin{tabular}{|l|c|c|}
\hline $\begin{array}{c}\text { Ksediaan } \\
\text { Membayar }\end{array}$ & Kuantitas & $\begin{array}{c}\text { Prosen } \\
(\%)\end{array}$ \\
\hline Rp5.000 & 70 & 17,5 \\
Rp10.000 & 52 & 13 \\
Rp12.500 & 20 & 5 \\
\hline
\end{tabular}

\begin{tabular}{|l|c|c|}
\hline Rp15.000 & 20 & 5 \\
Rp20.000 & 23 & 5,75 \\
Rp25.000 & 5 & 1,25 \\
Rp30.000 atau lebih & 4 & 1 \\
\hline \multicolumn{1}{|c|}{ Jumlah } & $\mathbf{1 9 4}$ & $\mathbf{4 8 , 5}$ \\
\hline
\end{tabular}

3.7. Sekali Selama Hidup

Bersesedia Mebayar Sekali Selama hidup

\begin{tabular}{|l|c|c|}
\hline $\begin{array}{c}\text { Kesedian } \\
\text { Membayar }\end{array}$ & Kuantitas & $\begin{array}{c}\text { Prosen } \\
(\boldsymbol{\%})\end{array}$ \\
\hline 50-100 ribu & 107 & 26,75 \\
101-200 ribu & 58 & 14,5 \\
201-300 ribu & 22 & 5,5 \\
Lebih 300 ribu & 2 & 0,5 \\
\hline \multicolumn{1}{|c|}{ Jumlah } & $\mathbf{1 8 9}$ & $\mathbf{4 7 , 2 5}$ \\
\hline
\end{tabular}

3.8. Tabulasi Silang Responden dengan WTP Membayar

Tabulasi silang responden mendukung tradisi budaya sadranan Cepogo dengan model membayar WTP

\begin{tabular}{|l|l|l|l|l|}
\hline \multicolumn{1}{|c|}{ Responden } & \multicolumn{1}{|c|}{$\begin{array}{c}\text { Tidak mau } \\
\text { bayar }\end{array}$} & $\begin{array}{c}\text { WTP/tahun } \\
\text { selama 12 Tahun }\end{array}$ & $\begin{array}{c}\text { WTP sekali } \\
\text { selama hidup }\end{array}$ & \multicolumn{1}{|c|}{ Jumlah } \\
\hline $\begin{array}{l}\text { Tidak mendukung } \\
\text { Mendukung }\end{array}$ & $17(4 \%$ & - & - & $17(4 \%)$ \\
\hline Jumlah & - & $194(48,5 \%$ & $189(47,5 \%)$ & $383(96 \%)$ \\
\hline
\end{tabular}

Renponden mendukung pelestarian budaya sadranan Cepogo sebanyak 96\% yang terdiri bersesedia membayar WTP setiap tahun selama sebanyak 47,5\%. Responden yang tidak mendukung dan tidak mau bayar WTP sebanyak $4 \%$.

12 tahun sebnyak 48,5\% dan sekali selama hidup

3.9. Tabulasi Silang Dukungan Pelestarian Tradidisi Budaya Sadranan Cepogo dengan Pendidikan Responden

Tabulasi Silang Dukungan Pelestarian Tradidisi Budaya Sadranan Cepogo dengan Pendidikan Responden

\begin{tabular}{|l|l|l|l|l|l|l|}
\hline \multicolumn{1}{|c|}{ Dukungan } & \multicolumn{1}{|c|}{$\begin{array}{c}\text { Tidak } \\
\text { Sekolah }\end{array}$} & \multicolumn{1}{|c|}{ SD } & \multicolumn{1}{|c|}{ SLTP } & \multicolumn{1}{|c|}{ SLTA } & $\begin{array}{l}\text { Perguruan } \\
\text { Tinggi }\end{array}$ & \multicolumn{1}{|c|}{ Jumlah } \\
\hline Tidak mendukung & $6(1,4 \%$ & $11(2,6 \%$ & - & - & - & $17(4 \%)$ \\
Mendukung & $10(2,6 \%$ & $106(26,65 \%$ & $132(33 \%)$ & $111(27,75 \%)$ & $24(6 \%)$ & $383(96 \%)$ \\
\hline Jumlah & $\mathbf{1 6 ( 4 \% )}$ & $\mathbf{1 1 7}(\mathbf{2 9 , 2 5})$ & $\mathbf{1 3 2 ( 3 3 \% )}$ & $\mathbf{1 1 1}(\mathbf{2 7 , 7 5 \% )}$ & $\mathbf{2 4 ( 6 \% )}$ & $\mathbf{4 0 0 ( 1 0 0 \% )}$ \\
\hline
\end{tabular}

Responden yang mendukung tradisi budaya sadranan Cepogo sebanyak 96\% mereka berpendidikan sekolah dasar sebanyak 26,65\%, berpendidikan

SLTP sebanyak $33 \%$, berpendidikan SLTA sebanyak 27,75\%, berpendidikan Perguruan Tinggi sebanyak 6\% 
dan tidak sekolah 4\%. Yang tidak mendukung pelestarian tradisi budaya sadranan Cepogo sebanyak $4 \%$ terdiri dari tidak sekolah sebanyak $1,4 \%$ dan sekolah dasar sebanyak 2,6\%.

\subsection{Tabulasi Silang Dukungan Pelestarian Tradisi Budaya Sadranan Cepogo dengan Jarak/Domisili Responden}

Responden yang mendukung pelestarian tradisi budaya sadranan Cepogo sebanyak 96\% mereka berjarak/domisili antara $<100-150 \mathrm{~km}$ $0 \%$, berjarak/domisili antara >150-200 km sebanyak $19,5 \%$, berjarak/domisili antara $>200$ 250 sebanmyak $59,5 \%$ dan diatas $250 \mathrm{~km}$ sebanyak $17 \%$. Responden yang tidak mendukung pelestarian tradisi budaya Sadranan Cepogo sebayak 4\%, mereka yang berjarak/domisili antara 150-200 km sebanyak 1,4\% dan berjarak/domisili lebih dari $250 \mathrm{~km}$ sebanyak $2,6 \%$.

Tabulasi Silang Dukungan Pelestarian Tradisi Budaya Sadranan Cepogo dengan Jarak/Domisili Responden

\begin{tabular}{|c|c|c|c|c|c|}
\hline \multirow[t]{2}{*}{ Responden } & \multicolumn{3}{|c|}{\begin{tabular}{|l|l|} 
Jarak (domisili) & Jarak (domisli) \\
Jarak (domisili)
\end{tabular}} & \multirow{2}{*}{$\begin{array}{c}\text { Jarak (domisili) } \\
>250 \mathrm{Km}\end{array}$} & \multirow[t]{2}{*}{ Jumlah } \\
\hline & $<100-150 \mathrm{Km}$ & $>150-200 \mathrm{Km}$ & $>200-250 \mathrm{Km}$ & & \\
\hline Tidak mendukung & $5(1,4 \%)$ & - & - & $12(2,6 \%)$ & $17(4 \%)$ \\
\hline Mendukung & - & $80(19,5 \%)$ & $240(59,5)$ & $64(17 \%)$ & $383(96 \%)$ \\
\hline Jumlah & $5(1,4 \%)$ & $80(19,5 \%)$ & $240(59,5 \%)$ & $75(19,6 \%$ & $400(100 \%)$ \\
\hline
\end{tabular}

\subsection{Tabulasi Silang Dukungan Pelestarian} Tradisi Budaya Sadranan Cepogo dengan Usia Responden

Responden yang mendukung pelestarian tradisi budaya sadranan Cepogo sebanyak 96\% mereka berusia antara 21-34 tahun sebanyak $18,4 \%$, berusia antara 35-48 tahun sebanyak

Tabulasi Silang Dukungan Pelestarian Tradisi Budaya Sadranan Cepogo dengan Usia Responden

\begin{tabular}{|l|l|l|l|l|l|}
\hline \multicolumn{1}{|c|}{ Respoden } & \multicolumn{1}{|c|}{$\begin{array}{c}\text { Usia } \\
<\mathbf{2 1} \text { tahun }\end{array}$} & $\begin{array}{c}\text { Usia antara } \\
\mathbf{2 1 - 3 4} \text { tahun }\end{array}$ & $\begin{array}{c}\text { Usia antara } \\
\mathbf{3 5 - 4 8} \text { tahun }\end{array}$ & $\begin{array}{c}\text { Usia } \\
>\mathbf{4 8} \text { tahun }\end{array}$ & \multicolumn{1}{|c|}{ Jumlah } \\
\hline Tidak mendukung & $8(1,9 \%)$ & - & - & $9(2,1 \%)$ & $17(4 \%)$ \\
Mendukung & - & $74(18,4 \%)$ & $245(61,5 \%)$ & $64(16,1 \%)$ & $383(96 \%)$ \\
\hline Jumlah & $\mathbf{8 ( 1 , 9 \% )}$ & $\mathbf{7 4 ( 1 8 , 4 \% )}$ & $\mathbf{2 4 5}(\mathbf{6 1 , 5 \% )}$ & $\mathbf{7 3 ( 1 8 , 2 \% )}$ & $\mathbf{4 0 0 ( 1 0 0 \% )}$ \\
\hline
\end{tabular}

\subsection{Nilai Bukan Gunaan (NBG) Tradisi} Budaya Sadranan Cepogo

Nilai NBG tradisi budaya sadranan Cepogo diestimasi dengan menggunakan CVM pertanyaan terbuka. Model pertanyaan terbuka, model ini dilakukanyang pertama dalam penelitian CVM. Pelaksanaannya responden ditanya jumlah maksimum kesediaan membayar (WTP) tentang tradisi budaya sadranan Cepogo. Responden mempunyai kebebasan menyatakan jumlah maksimum sesuai kemampuannya.
$61,5 \%$, berusia diatas 48 tahun sebanyak 16,1\%. Responden yang tidak mendukung pelestarian tradisi budaya Sadranan Cepogo senayak 4\% mereka berusia dibawah 21 tahun sebanyak 1,9\% dan berusia lebih dari 48 tahun sebanyak 2,1\%. 
tradisi budaya tersebut diperlukan penyisipan budaya tersebut selama generasi baru tersebut masih berada pada masa pendidikan dasar sampai menengah atas atau selama 12 tahun.

Nilai tradisi budaya sadranan selain dari perspekti masyarakat pengguna dan komunitas Cepogo juga dimiliki oleh masyarakat bukan pengguna. Walaupun masyarakat bukan pengguna secara langsung tidak menikmati jasa tradisi budaya sadranan Cepogo. Tulisan ini membicarakan dan memperbincangkan sebagian komponen nilai bukan gunaan (NBG) yang membentuk nilai penggunaan pasif (NPP).

Pasaran yang dibentuk untuk mendapatkan WTP pelestarian tradisi budaya sadranan Cepogo dari masyarakat bukan pengguna; tradisi budaya sadranan Cepogo merupakan budaya yang unik spiritual dan juga berfungsi sebagai wahana silaturahim pemersatu warga. Tradisi budaya tersebut perlu dilestarikan oleh generasi baru.

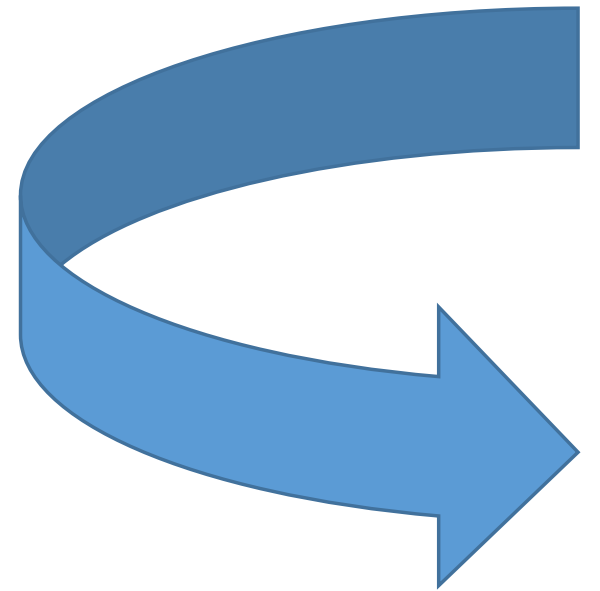

\section{Responden Bersedia Membayar}

194(48,5\%)

Membayar

Per tahun

Selama

12 tahun

Nilai tradisi budaya sadranan Cepogo nilai bukan gunaan (NBG) merupakan rata-rata kesediaan melestarikan tradisi budaya Cepogo
Pelestarian tersebut perlu adanya pemahaman generasi baru sewaktu masih berada pada pendidikan dasar sampai menengah atas yang memerlukan dana pemahaman. Bersediakah anda menyokong dan membayar dana pelestarian tradisi budaya Cepogo. Dana tersebut akan digunakan untuk pemahaman yang disisipkan sewaktu generasi baru belajar di pendidikan dasar sampai menengah atas.

Selanjutnya masyarakat bukan pengguna ditanya apakah bersedia membayar rekening pelestarian budaya sadranan Cepogo. Sistem pembayaran disediakan dengan 2 (dua) jenis yaitu; membayar setiap tahun sekali selama 12 (duabelas tahun) dan membayar selaki selama hidup. Secara ringkas kesediaan masyarakat bukan pengguna sebanyak 400 (100\%) yang bersedia membayar $383(96 \%)$ seperti diagram dibawah:

Kesediaan melestarikan tradisi budaya sadranan Cepogo WTP ${ }^{\mathrm{a}} 1$ kali selama 12 Tahu

\begin{tabular}{|l|l|l|}
\hline \multicolumn{1}{|c|}{ URAIAN } & \multicolumn{1}{|c|}{ WTP $^{\text {a }}$} & \multicolumn{1}{c|}{ JARAK/DOMOSILI } \\
\hline Rata-rata & Rp 392.867,70 & $169,25 \mathrm{~km}$ \\
Minimal & Rp 0,- & $151,62 \mathrm{~km}$ \\
Maksimal & Rp 980.127,30 & $314,47 \mathrm{~km}$ \\
Standar deviasi & $262.584,21$ & 29,79 \\
\hline
\end{tabular}

Kesedian melestarikan tradisi budaya sadranan Cepogo WTP ${ }^{\mathrm{b}}$ sekali selama Hidup

\begin{tabular}{|l|l|l|}
\hline \multicolumn{1}{|c|}{ URAIAN } & \multicolumn{1}{|c|}{ WTPb } & \multicolumn{1}{c|}{ JARAK/DOMISILI } \\
\hline Rata-rata & Rp 119.315,- & $226,51 \mathrm{~km}$ \\
Minimal & Rp 0,- & $151 \mathrm{~km}$ \\
Maksimal & Rp 392.000,- & $314,15 \mathrm{~km}$ \\
Standar deviasi & $79.713,64$ & 42,69 \\
\hline
\end{tabular}


Kesediaan melestarikan tradisi budaya sadranan Cepogo (WTP) perspektif masyarakat bukan pengguna yang merupakan NBG membentuk nilai penggunaan pasif (NPP) dapat diformalisasikan dalam model:

\begin{tabular}{|llll|}
\hline Variabel & Coefisioner & Statistik 't' & VIF \\
\hline Domisili (Dm) & $-473,59$ & $-3,756^{* * *}$ & 1,729 \\
Pendapatan (Pdt) & 94726,36 & $16,945^{* * *}$ & 3,030 \\
Usia(U) & 7121,68 & $7,009^{* * *}$ & 3,213 \\
Kontanta & -355089 & $-7,744^{* * *}$ & \\
\hline Statistik R & 0,861 & & \\
Adjusted R & 0,858 & & \\
Statistik F & $404,2 * * *$ & & \\
Statistik D-W & 2,431 & & \\
Condition Index & 29.944 & & \\
Sampel (n) & 383 & & \\
\hline
\end{tabular}

Model yang dibuat variabel bebas yaitu domisili responden, pendapatan responden, usia responden dapat memberikan penjelasan kesediaan membayar guna melestarikan tradisi budaya sadranan Cepogo (WTP) sebesar 86,1\% diselaraskan menjadi $85,8 \%\left(\mathrm{R}^{2}\right)$. Sedang yang sebesar $14,2 \%$ dijelaskan oleh variabel-variabel lain yang tidak terkaper dalam model, ini menunjukkan bahwa model yang dibuat sangat baik. Ketiga varibel bebas yang dimasukkan dalam model secara bersama-sama dapat menjelaskan variabel terikat (WTP) yang ditunjukkan nilai $\mathrm{F}$ yang diatas 4(empat). Model juga tidak mengalami masalah kolinearitas dan autokorelasi berdasarkan Conditional index (CI) dan Durbin Watson (D-W).

Variabel domisili berhubungan negatif dengan WTP dan signifikan pada tingkat kepercayaan $1 \%$. Ini artinya respoden yang domisilinya semakin jauh dari lokasi penelitian mereka memberikan WTP semakin rendah. Apabila faktor lain tidak berubah pertambahan jarak domisili responden setiap bertambah lehih jauh 1kilometer WTP berkurang sebesar Rp473,60 temuan ini tidak jauh berbeda dan sesuai dengan penelitian Hanley at al (1989). Hubungan negatif variabel jarak domisili dengan
$\mathbf{W T P}=\alpha+\beta_{\mathbf{1}} \mathrm{Dm}+\boldsymbol{\beta}_{\mathbf{2}}$ Pdt $+\boldsymbol{\beta}_{\mathbf{3}} \mathrm{U}+\boldsymbol{\varepsilon}$

Dimana analisis kesediaan WTP tersebut dengan OLS adalah diperoleh hasil:
WTP dapat untuk dasar menentukan batas awal respon bukan pengguna.

Variabel pendapatan berhubungan positif dengan WTP dengan signifikan pada tingkat kepercayaan $1 \%$. Ini artinya semakin besar pendapatan masyarakat memberikan WTP semakin besar. Koefisien variabel pendapatan nenunjukkan pengaruh perubahan peningkatan yang besar, artinya kesadaran masyarakat dalam pelestarian budaya apalagi budaya yang dapat menimbulkan kerukunan melalui wahana silaturahim mereka bersedian mengorbankan pendapatan agar tradisi budaya tesebut tetap lestari. Setiap bertambahnya pendapatan sebesar Rp1 juta, WTP akan bertambah sesar Rp94.726,36 dengan asumsi hal-hal lain tidak berubah.

Variabel umur secara statistik mempunyai hubungan positif dengan WTP dan signifikan pada tingkat kepercayaan $1 \%$. Ini berarti semakin bertambah usia responden akan bertambah kesediaan melestarikan tradisi budaya sadranan (WTP). Sehingga tepat perlu adanya pemahaman kepada gererasi baru atau perlu adanya pengenalan budaya pada genenari calon penerus. 


\section{Kesimpulan}

Budaya sadranan Cepogo mempunyai nilai baik perspekstif dari masyarakat penguna maupun dari perspektif masyarakat bukan pengguna atau dikenal Nilai Bukan Gunaan (NBG). Berkurangnya masyarakat Cepogo yang melaksanakan budaya sadranan dan terjadinya pemahaman yang keliru dalam upacara sadranan dampaknya tidak hanya berpengaruh pada masyarakat pengguna setempat tetapi juga berpengaruh pada masyarakat bukan pengguna. Dalam penelitian ini masyarakat bukan pengguna juga ada kesediaan melestarikannya. Kesediaan menyisihkan dana dalam rangka partisipasinya mendukung sosialisasi pada generasi penerus sehingga budaya sadranan tetap ada dan tidak terjadi pemahanan yang keliru antara budaya dan agama.

Tradisi budaya sadranan tersebut perlu dilestarikan dan berpeluang mendukung pariwisata yang unik. Pengembangan pariwisata yang berbasis budaya dan agama perlu ada sentuhan kepada masyarakat setempat, pelaku serta fasilitas pendukung sehingga wisatawan tertarik dan menjadikan daerah tersebut sebagai distinasinya berwisata. Kehalalan pariwisata juga perlu mendapat sentuhan baik halal obyeknya, halal kulinernya dan halal pendungnya. Kondisi tersebut sangat menjadi pertimbangan wisatawan muslim dalam berkunjung disuatu obyek atau distinasi.

\section{Daftar Pustaka}

Abeysekera, I. 2007. Intellectual capital reporting between a developing and developed nation. Journal of Intellectual Capital, 8 (2): 329-345.

Agus Maladi Irianto, 2017. Kesenian Tradisional

Sebagai Sarana Strategi Kebudayaan di Tengah Determinasi. Jurnal NUSA. Vol 12. Nomer.1.

Arivia Gadis dan Abby Gina, 2015. Culture, Sex and Religion: a Study of Contract-Marriage in Cisarua and Jakarta. Jurnal Perempuan Vol.20.No.1. 57-64.

Black Steward J. And Lyman W Poster. 2000. Management: Meeting New Challenges. New Jersey: Prentice Hall Inc.
Debby Willar, Jerry Lintong, dan Revleen Kaparang, 2015. Identifikasi Profil Budaya Organisasi Yang Memdukung Implementasi Mutu Perguruan Tinggi. Jurnal Ilmiah Pendidikan. Edisi Juni XXXIV. No.2.ISSN 0216-1370.

Hit, Michael A., R.. Duane Ireland dan Robet Hoskinson. 2001. Managewment Strategis: Daya Saing dan Globalisasi. Jakarta: Salemba Empat.

Hanley, N.D. 1989. Valuing Rural Recreation Benefits: An Aprical Empirical Comparation of Two Approaches. Journal of Agricultural Economic.40: 361-374.

Kayam, Umar. 1996. Kebudayaan dan Budaya Perusahaan. Manajemen Usahawan Indonesia $07 / \mathrm{XXV}$.

Ladiyanto, Erlangga Agustino and Wardaya, Wirya. 2009. Framework of Regional Development in Agenda 21: Sustainability and Environmental Vision. Airlangga University dalam http://mpra.ub.unimuenchen.de/2381/

Rapi Gopal. 2005. Indigenous Environmental Knwoledge in Formal Education. Journal Penyelidikan. MPBL.6

Soo-Hoon Lee., Poh Kam Wong and Chee Leong Chong. 2005. Human and Sosial Capital Explanation for R\&D Outcomes IEEE Transactions on Engineering Management. 52 (1) p 59-68.

Susanto, A.B., Sujanto FX., Wijanarko Himawan. 2008. Corporate Culture Organization Culture. The Jakarta Culsulting Group.

Sri Walyoto, 2011. Analisis Ekonomi Impak Alam Sekitar dan Budaya. Thesis. Universiti Kebangsaan Malaysia.

2018. Economic Analysis of Enviromental and Cultural Impacts of the Development of Palm Oil Plantation. International Journal of Energy Economics and Policy. 2018. Carbon Costs of Indonesia Forested Land Conversion to Oil Palm Plantations. Shirkah. Journal of Economics and Business, Vol 3 No.3. 
Jurnal Ilmiah Ekonomi Islam, 5(03), 2019, 196

2019. Nilai Ekonomi Umbul Pengging

Sebagai Area Tujuan Wisata. Jurnal Inferensi

IAIN

Salatiga.http://inferensi.iainsalatiga.ac.id/ind ex.php/inferensi/article/view/1040

Sardiman,AM, 1992. Konsep Kekuasan Dalam Tradisi Budaya Jawa. Jurnal Cakrawala Pendidikan. Nomer I Tahun XI, Februari 1992.

Taylor, Edward.1920. [1871]. Primitive Culture.

New York: J.P. Putnam's Sons.410. Throsby,

David, 1999.Cultural Capital. Journal of

Cultural Economics, 23 (1-2): 3-12.
Throsby, David. 1997. Sustainability and Culture: Some Theoritical Inssues. The International Journal of Culture Policy. JCPOEW 4 (1) 1242.

Azzam, H.T., (2002). There's considerable rationale to invest in Arab stock markets, Middle East Executive Reports 25, 6-10.

Erdem, C., Arslan, C. K., \& Sema Erdem, M. (2005). Effects of macroeconomic variables on Istanbul stock exchange indexes. Applied Financial Economics, 15(14), 987-994. 